\title{
Reversal Effects of N-Acetyl Cysteine on Moringa oleifera Leaves-Induced Sub-Acute Hepatotoxicity in Wistar Albino Rats
}

\author{
Josephine N. Kasolo ${ }^{*}$ (i), Agnes Namaganda1, Godfrey S. Bbosa ${ }^{2}$, Haruna Muwonge ${ }^{1}$, \\ Robert Lukande ${ }^{3}$, Joshua Nfambi' ${ }^{1}$, Ivan Kimuli' ${ }^{1}$, Isaac Okullo ${ }^{4}$ \\ ${ }^{1}$ Department of Medical Physiology, College of Health Sciences, Makerere University, Kampala, Uganda \\ ${ }^{2}$ Department of Pharmacology and Therapeutics, College of Health Sciences, Makerere University, Kampala, Uganda \\ ${ }^{3}$ Department of Pathology, College of Health Sciences, Makerere University, Kampala, Uganda \\ ${ }^{4}$ Department of Dental Surgery, College of Health Sciences, Makerere University, Kampala, Uganda \\ Email: ${ }^{*}$ jkasolo@chs.mak.ac.ug, ${ }^{*}$ josephinekasolo57@gmail.com
}

How to cite this paper: Kasolo, J.N., Namaganda, A., Bbosa, G.S., Muwonge, H., Lukande, R., Nfambi, J., Kimuli, I. and Okullo, I. (2019) Reversal Effects of N-Acetyl Cysteine on Moringa oleifera Leaves-Induced SubAcute Hepatotoxicity in Wistar Albino Rats. Neuroscience \& Medicine, 10, 385-397. https://doi.org/10.4236/nm.2019.104028

Received: November 20, 2019 Accepted: December 21, 2019 Published: December 24, 2019

Copyright $\odot 2019$ by author(s) and Scientific Research Publishing Inc. This work is licensed under the Creative Commons Attribution International License (CC BY 4.0).

http://creativecommons.org/licenses/by/4.0/

\begin{abstract}
Background: $M$. oleifera is a highly valued medicinal plant used widely from time immemorial to treat various ailments. However, with continued un-standardized use of the plant leaves, studies have reported organ toxicity to the liver, kidney and the heart. As communities continue to use M. oleifera leaves for its medicinal and nutritional values, there is need to find an antidote for its hepatotoxicity. Aim: The study established the reversal effect of N-Acetyl Cysteine (NAC) on M. oleifera aqueous leaf extract-induced hepatotoxicity in Wistar albino rats. Methods: Twenty-four (24) rats received a toxic dose (8.05 $\mathrm{g} / \mathrm{kg}$ bwt) of $M$. oleifera leaf extract for 28 days to cause sub-acute hepatotoxicity. They were divided into 4 groups of 6 rats each. Group I received $1 \mathrm{ml}$ normal (control group), Group II received 1000 ng/kg NAC, Group III received $1200 \mathrm{mg} / \mathrm{kg} \mathrm{NAC}$ and Group IV received $1500 \mathrm{mg} / \mathrm{kg} \mathrm{NAC}$. Another group of 6 rats (Group V) received $0.75 \mathrm{mg} / \mathrm{kg}$ Paracetamol to cause hepatotoxicity. Group V (a positive control) received the prescribed clinical dose of $1200 \mathrm{mg} / \mathrm{kg}$ NAC which reverses the hepatotoxicity. All the NAC doses were given once a day intragastric for 7 days. On days: 1, 3 and 7 of receiving NAC, liver serum enzymes and bilirubin were measured. On day 7 the animals were sacrificed and liver tissue harvested for histopathology analysis. Results: A dose of $8.05 \mathrm{~g} / \mathrm{kg}$ of $M$. oleifera leaf extract and $0.75 \mathrm{mg} / \mathrm{kg}$ Paracetamol were able to induce hepatotoxicity in Wister albino rats in 28 days. The $M$. oleifera extract induced hepatotoxic rats treated with NAC at doses of $1000 \mathrm{mg} / \mathrm{kg}$, $1200 \mathrm{mg} / \mathrm{kg}$ and $1500 \mathrm{mg} / \mathrm{kg}$, had a reduction in mean serum liver enzymes, plus reduced mean serum bilirubin levels. The liver histopathological analysis
\end{abstract}


showed reduced inflammation after treatment with NAC for 3 and 7 days in the $M$. oleifera and paracetamol induced hepatotoxic rats. Conclusion: NAC can reverse $M$. oleifera leaf aqueous extract-induced sub-acute hepatotoxicity in Wistar Albino rats.

\section{Keywords}

M. oleifera, Sub-Acute Hepatotoxicity, N-Acetyl Cysteine, Wistar Albino Rat

\section{Introduction}

Traditional medicines especially using medicinal plants still remain a key component in human life. However, there are growing concerns related to the safety and toxicities of these herbal medicines derived from the medicinal plants. These herbal medicines cause various organ toxicities such as liver damage with a high incidence of mortality and morbidity. Among the commonly used medicinal plants is Moringa oleifera (M. oleifera). It was initially grown in tropical \& subtropical countries and more recently, worldwide [1]. It is part of a consortium of medicinal plants that $80 \%$ of the world's population depends on as first line therapy for disease alleviation [2]. In many regions of Africa, it is widely consumed as self-medication by patients with diabetes, hypertension, or HIV/AIDS [3]. All the plant parts are traditionally used for different purposes, but the leaves are generally the most used. The rural communities in Uganda, use its leaves to treat 24 common medical conditions, including diabetes mellitus, asthma, bronchitis, mastitis, skin conditions, worm infestations, and HIV/AIDS symptoms among others [4]. M. oleifera's leaves ability to treat most of these conditions has been attributed to the various phytochemical compounds present in the plant parts including its leaves [4]. They are reported to be a rich source of alkaloids and oxalates, and these have been reported to be toxic to the body including the liver [5], thus requiring other medications to reverse these toxic effects. Studies done earlier found out that the LD50 of $M$. oleifera leaves' aqueous extract was $16.10 \mathrm{~g} / \mathrm{kg}$ [6]. A sub-acute toxicity profile done on rats whereby $1 / 2$ lethal dose $(8.05 \mathrm{~g} / \mathrm{kg}), 1 / 4 \mathrm{LD} 50(4.0 \mathrm{~g} / \mathrm{kg})$ and 1/16 LD50 (2.0 g/ $\mathrm{kg})$ of $M$. oleifera leaves aqueous extract was given intragastrically to different groups of rats for 28 days. They found hepatotoxicity, renal toxicity and heart toxicity in rats that received $1 / 2$ lethal dose while the doses below that were not affected. It was concluded that a dose of $8.05 \mathrm{~g} / \mathrm{kg}$ caused sub-acute organ toxicity [7]. The reversal of these hepatic toxic effects induced by phytochemical free radical can be achieved by use of antioxidants. Several antioxidants have been used with varying degrees of success. However, not surprisingly, $\mathrm{N}$-acetyl cysteine (NAC), which supplies the cysteine necessary for glutathione synthesis, has proven more effective in treating disease-associated to reactive free radicals organ damage [8]. N-Acetyl cysteine belongs to a family of antioxidant compounds that are commonly used to manage a number of drug or disease-related toxicities, including glutathione defi- 
ciency and acetaminophen toxicity [9]. Although toxic levels of $M$. oleifera are known to cause organ toxicity, limited studies have examined the possibility of reversal of these effects. Moreover, no study has been done to document the effect of NAC in M. oleifera aqueous leaf extract induced hepatotoxicity. Therefore, this study established the reversal of $\mathrm{N}$-acetyl cysteine on $M$. oleifera aqueous leaf extract induced-sub-acute hepatotoxicity in Wistar Albino rats.

\section{Materials and Methods}

\section{Study design and setting}

It was a laboratory-based experimental study whereby $M$. oleifera leaves were collected from Mukono a central Uganda district, collected at 11:00 am during the dry season. The processing of the plant leaves and the laboratory experiments were done at the department of Medical Physiology, Makerere University College of Health Sciences. Experiments were done according to internationally approved methods [10] [11].

\section{Plant collection and identification}

M. oleifera leaves were harvested plus having the family and species of the leaves confirmed by a Makerere University plant taxonomist and a voucher specimen number $(41,302)$ was deposited at the Makerere University herbarium. The laveas were air dried in a shade until constant weight was attained. They were pound using a motor and pestle into course powder for extraction.

\section{Extracts preparation}

The extraction process followed the already established extraction procedure on the plant materials [11]. About $300 \mathrm{~g}$ of M. oleifera leaf powder were weighed using an electronic weighing scale (Mettler PJ3000, Mettler-Toledo GmbH, Ockerweg, Germany), and then soaked in 1.3 litres of hot water $\left(96^{\circ} \mathrm{C}\right)$ to prevent fungal attacked and allowed to cool while being shaken at 3 hourly intervals for 12 hours. The resulting suspension was filtered using a Whatman No. 1 filter paper in a Buchner funnel. The filtrate was freeze dried at $32 \mathrm{~Pa}$ with an original temperature set at $-47^{\circ} \mathrm{C}$ and then maintained at $0^{\circ} \mathrm{C}$ to dry the extract. A freeze dryer (Genesis 12 ES) in the Chemistry department laboratory at Makerere University was used to dry the extract. The extracts obtained were stored in an air tight bottle, wrapped in a silicon paper to prevent moisture and was dissolved in distilled water to make stock solution.

Drugs: N-acetyl cysteine (NAC) used as the antioxidant for reversing the $M$. oleifera and paracetamol induced-hepetotoxicity. $\mathrm{N}$-acetyl cysteine (NAC) was purchased from NOWFOODS, 244 Knollwood Dr, Bloomingdale, IL. 60108 USA. Normal saline was used as the negative control and paracetamol caused hepatotoxicity and was used as a positive control.

\section{Animal handling}

Thirty six disease-free Wistar albino rats aged between 6 and 8 weeks of which 24 were randomized into experimental groups. They were bred at the Makerere University College of Veterinary Medicine Animal Resources and Biosecurity 
(CoVAB), animal house, transferred to Department of Medical Physiology animal house at Makerere University College of Health Sciences for the study. The rats were kept at standard laboratory conditions of temperature $\left(25^{\circ} \mathrm{C} \pm 1^{\circ} \mathrm{C}\right)$, relative humidity (45\% - 55\%) having $12 \mathrm{hr}$ light and $12 \mathrm{hr}$ darkness. Standard commercial rat pellets and clean water were provided Ad libitum [10].

\section{Dosing of animals}

Twenty-four (24) rats received a toxic dose $(8.05 \mathrm{~g} / \mathrm{kg}$ bwt $)$ of $M$. oleifera leaf extract for 28 days to cause sub-acute hepatotoxicity. They were divided into 4 groups of 6 rats each. Group I received $1 \mathrm{ml}$ normal saline which acted as a control group, Group II received 1000 ng/kg NAC, Group III received 1200 mg/kg NAC and Group IV received $1500 \mathrm{mg} / \mathrm{kg}$ NAC. Another group of 6 rats (Group $\mathrm{V})$ received $0.75 \mathrm{mg} / \mathrm{kg}$ Paracetamol to cause hepatotoxicity. For Group V which was a positive control received the prescribed clinical dose of $1200 \mathrm{mg} / \mathrm{kg} \mathrm{NAC}$ which reverses the hepatotoxicity. All the NAC doses were given once a day intragastric for 7 days.

\section{Reversal effects of NAC on $M$. oleifera sub-acute hepatotoxicity}

Groups II to IV were used to test reversal effect of ANC on M. oleifera leaves extract induced-hepatotoxicity and Group V rats were used to confirm the reversal effect of ANC on paracetamol induced hepatotoxicity. Group I acted as the control group. After 28 days of receiving the M. oleifera extract and Paracetamol, hepatotoxicity was confirmed by elevated liver enzymes: ALT(U/L) 95.60 \pm 14.40 , over 2 times upper limit of normal; AST(U/L) $216.30 \pm 2.30$; over 5 times upper limit of normal; ALP(U/L) $181.05 \pm 18.95$; Total BIL $(\mu \mathrm{mol} / \mathrm{L}) 0.35 \pm$ 0.04; Total protein $(\mathrm{g} / \mathrm{L}) 64.65 \pm 5.75$.

NAC was given intragastric once a day for 7 days. Blood was withdrawn from a tail vein and serum harvested on days 1, 3 and 7 for liver enzymes and bilirubin measurements.

On day 7 they were then sacrificed, blood taken from the heart puncture, centrifuged and serum harvested. Serum proteins, bilirubin, AST, ALP, and ALT were measured by the COBA-e-411 Clinical chemistry analyzer instrument (Roche diagnostics, Germany) using methods described by the manufacturer.

\section{Histopathology of the liver}

The liver tissues were harvested by soaking cotton wool in concentrated ethyl ether and putting it close to their nostrils which caused them to sleep for good. The abdominal walls were opened and a piece of liver tissue was removed. They were placed into formalin buffer $10 \%$, processed and sections of $5 \mathrm{~mm}$ thickness were prepared by a histopathologist, stained with Hematoxicylin and Eosin and examined under light microscope at $\times 10$ maginification.

\section{Data management \& Analysis}

Data was entered into a Microsoft Excel spread sheet and exported to GraphPad prism 8.0a Software (GraphPad Software Inc., California, USA) for analysis. Comparisons of means and standard deviations of serum enzymes and serum bilirubin were made between day one against those of day 3 and 7 by the two-way 
analysis of variance (ANOVA) using Dunnett's multiple comparison's test. Mean values of $\mathrm{P} \leq 0.05$ were considered to be statistically significant.

\section{Ethical considerations}

Permission to conduct the study was sought from the Department of Physiology and the School of Biomedical Sciences Institutional Review Board (IRB). The protocol was approved and numbered SBC-HDREC-575. Ethical practices that govern handling of laboratory animals were adhered to as per international biosafety guidelines and the guidelines for the care and use of laboratory animals (Gordon, 2001).

\section{Results}

In this study, the rats that were pre-treated with a toxic dose of $8.05 \mathrm{~g} / \mathrm{kg}$ of $M$. oleifera leaf extract and those that received $0.75 \mathrm{mg} / \mathrm{kg}$ Paracetamol, showed a significant increase in mean serum liver enzymes and bilirubin levels on day 1 . However by day 7 there was reduction in the mean serum liver enzymes and bilirubin

On day 1 before giving NAC, the mean serum ALT was $99.95 \pm 0.05 \mathrm{U} / \mathrm{L}$ and on receiving $1000 \mathrm{mg} / \mathrm{kg} \mathrm{NAC}$ the mean serum levels had reduced to $91.45 \pm$ 1.95 (P-value 0.0288 ) on day 7. On day 1 before giving NAC, the mean serum ALT was $106.80 \pm 13.20 \mathrm{U} / \mathrm{L}$ and on receiving $1200 \mathrm{mg} / \mathrm{kg}$ NAC the mean serum levels had reduced to $60.80 \pm 1.00$ (P-value 0.0162 ) on day 7 ; on day 1 before giving NAC, the mean serum ALT was $113.80 \pm 16.20 \mathrm{U} / \mathrm{L}$ and on receiving 1500 $\mathrm{mg} / \mathrm{kg}$ NAC the mean serum levels had reduced to $46.70 \pm 3.50 \mathrm{U} / \mathrm{L}$ (P-value 0.0288 ) on day 7. Regarding the group that received paracetamol received 1200 $\mathrm{mg} / \mathrm{kg} \mathrm{NAC}$, the mean serum ALT was $117.05 \pm 33.05 \mathrm{U} / \mathrm{L}$ on day one and reduced to $51.40 \pm 2.80 \mathrm{U} / \mathrm{L}$ (P-value 0.0009 ) by day 7 (Figure 1 ).

The rats that received $1000 \mathrm{mg} / \mathrm{kg}$ NAC had mean serum AST level of 233.95 $\pm 80.05 \mathrm{U} / \mathrm{L}$ on day 1 and $91.50 \pm 2.40 \mathrm{U} / \mathrm{L}$ (P-value 0.0002 ) on day 3 , and rose again to $150.04 \pm 6.87 \mathrm{U} / \mathrm{I}$ on day 7 . However the rats that received $1200 \mathrm{mg} / \mathrm{kg}$ NAC had mean serum AST level of $180.90 \pm 35.10 \mathrm{U} / \mathrm{L}$ on day $1,136.35 \pm 3.85$ $\mathrm{U} / \mathrm{L}$ (P-value 0.0003 ) on day 3 and reduced again to $117.00 \pm 8.40 \mathrm{U} / \mathrm{I}$ on day 7 . The rats that received $1500 \mathrm{mg} / \mathrm{kg}$ NAC had mean serum AST level of $216.85 \pm$ $1.85 \mathrm{U} / \mathrm{L}$ on day $1,108.35 \pm 3.95$ (P-value 0.0001 ) on day 3 , and rose again to $141.73 \pm 5.22 \mathrm{U} / \mathrm{I}$ on day 7 . The Paracetamol group received $1200 \mathrm{mg} / \mathrm{kg} \mathrm{NAC}$, had a mean serum AST of $200.20 \pm 40.30 \mathrm{U} / \mathrm{L}$ on day 1and reduced to $114.85 \pm$ 14.25 U/L by day 7 (Figure 2).

The rats that received $1000 \mathrm{mg} / \mathrm{kg}$ NAC had mean serum ALP level of 175.10 $\pm 5.10 \mathrm{U} / \mathrm{L}$ on day 1 and $119.30 \pm 5.40 \mathrm{U} / \mathrm{L}$ (P-value 0.0022 ) on day 3 , and 109.60 \pm 9.60 (P-value 0.001 ) on day 7. However the rats that received $1200 \mathrm{mg} / \mathrm{kg} \mathrm{NAC}$ had mean serum ALP level of $175.10 \pm 5.10 \mathrm{U} / \mathrm{L}$ on day $1,117.20 \pm 4.90$ (P-value 0.0016 ) on day 3 and $110.90 \pm 5.60$ (P-value 0.0006 ) on day 7. The rats that received $1500 \mathrm{mg} / \mathrm{kg}$ NAC had mean serum ALP level of $181.70 \pm 21.70 \mathrm{U} / \mathrm{L}$ on day $1,103.80 \pm 5.30$ (P-value 0003) on day 3 , and $110.20 \pm 8.00$ (P-value 0.0005) on day 7. The Paracetamol group received $1200 \mathrm{mg} / \mathrm{kg} \mathrm{NAC}$, had a mean serum 


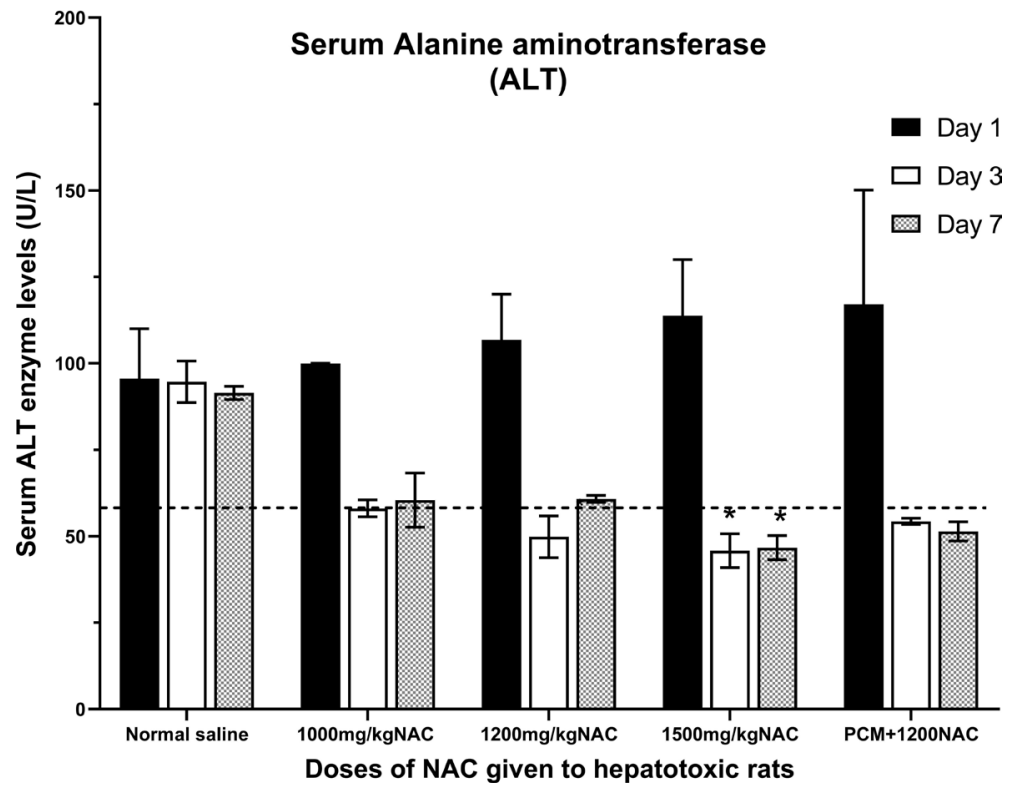

${ }^{*} \mathrm{P}<0.05$ was marked significant, $\mathrm{NS}=$ Normal saline, $\mathrm{NAC}=\mathrm{N}$-acetyl cysteine, and $\mathrm{PCM}=$ paracetamol; the dotted line indicates the normal ALT level.

Figure 1. Serum ALT levels in hepatotoxic rats treated with different doses of NAC.

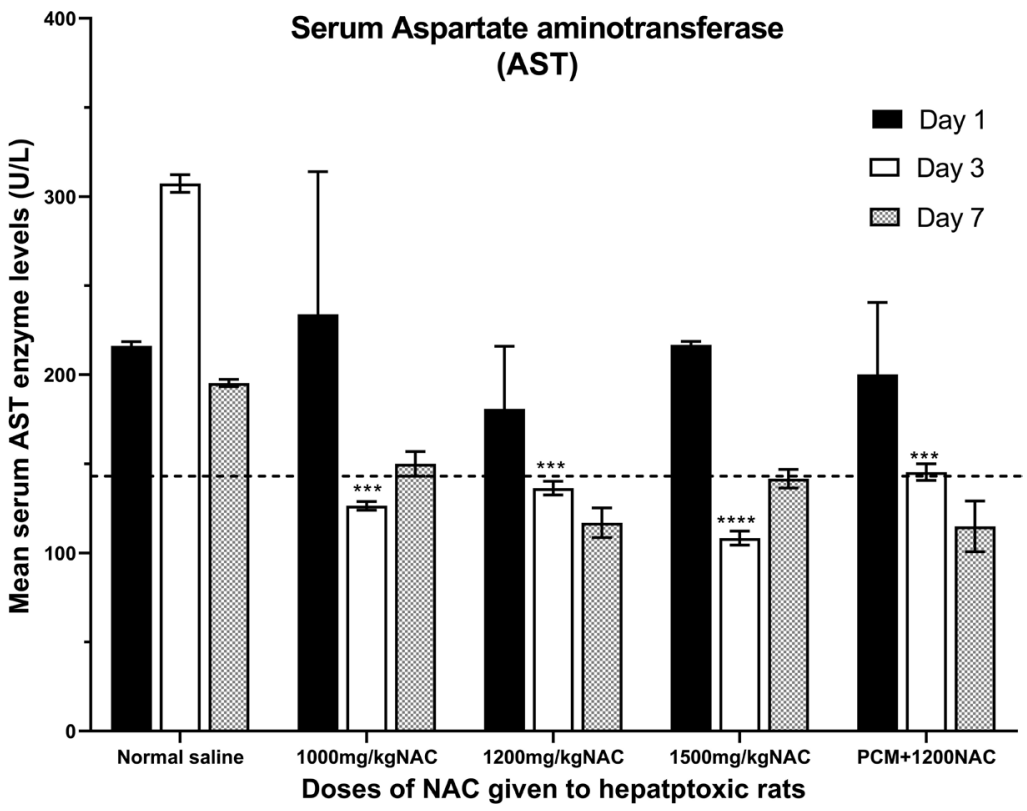

${ }^{\star} \mathrm{P}<0.05$ was marked significant, ${ }^{* *} \mathrm{P}<0.05$ was marked highly significant, NS $=$ Normal saline, NA $=\mathrm{N}$-acetyl cysteine, PCM $=$ Paracetamol; the dotted line indicates the normal AST levels.

Figure 2. Serum AST levels in hepatotoxic rats treated with different doses of NAC.

ALP of $164.95 \pm 25.05 \mathrm{U} / \mathrm{L}$ on day 1 and reduced to $103.05 \pm 1.35$ (P-value 0.0005 ) by day 7 (Figure 3 ).

The rats that received $1000 \mathrm{mg} / \mathrm{kg}$ NAC had mean serum bilirubin level of $0.31 \pm 0.03 \mu \mathrm{Mol} / \mathrm{L}$ on day $1,0.11 \pm 0.02 \mu \mathrm{Mol} / \mathrm{L}$ (P-value 0.0001 ) on day 3 , and $0.13 \pm 0.05 \mu \mathrm{Mol} / \mathrm{L}$ (P-value 0.0009 ) on day 7 . However the rats that received $1200 \mathrm{mg} / \mathrm{kg}$ NAC had serum bilirubin level of $0.27 \pm 0.02 \mu \mathrm{Mol} / \mathrm{L}$ on day $1,0.10$ 
$\pm 0.01 \mu \mathrm{Mol} / \mathrm{L}$ (P-value 0.0001$)$ on day 3 and $0.03 \pm 0.01 \mu \mathrm{Mol} / \mathrm{L}$ (P-value $0.0001)$ on day 7 . The rats that received $1500 \mathrm{mg} / \mathrm{kg}$ NAC had serum bilirubin level of $0.33 \pm 0.01$ (P-value 0.0001 ) on day $1,0.05 \pm 0.03$ (P-value 0.0001 ) on day 3 , and $0.10 \pm 0.02$ (P-value 0.0002 ) on day 7 . The Paracetamol group received $1200 \mathrm{mg} / \mathrm{kg} \mathrm{NAC}$, had a mean serum bilirubin of $0.24 \pm 0.00 \mu \mathrm{Mol} / \mathrm{L}$ on day 1 , and reduced to $0.13 \pm 0.09$ (P-value 0.0002 ) by day 7 (Figure 4 ).

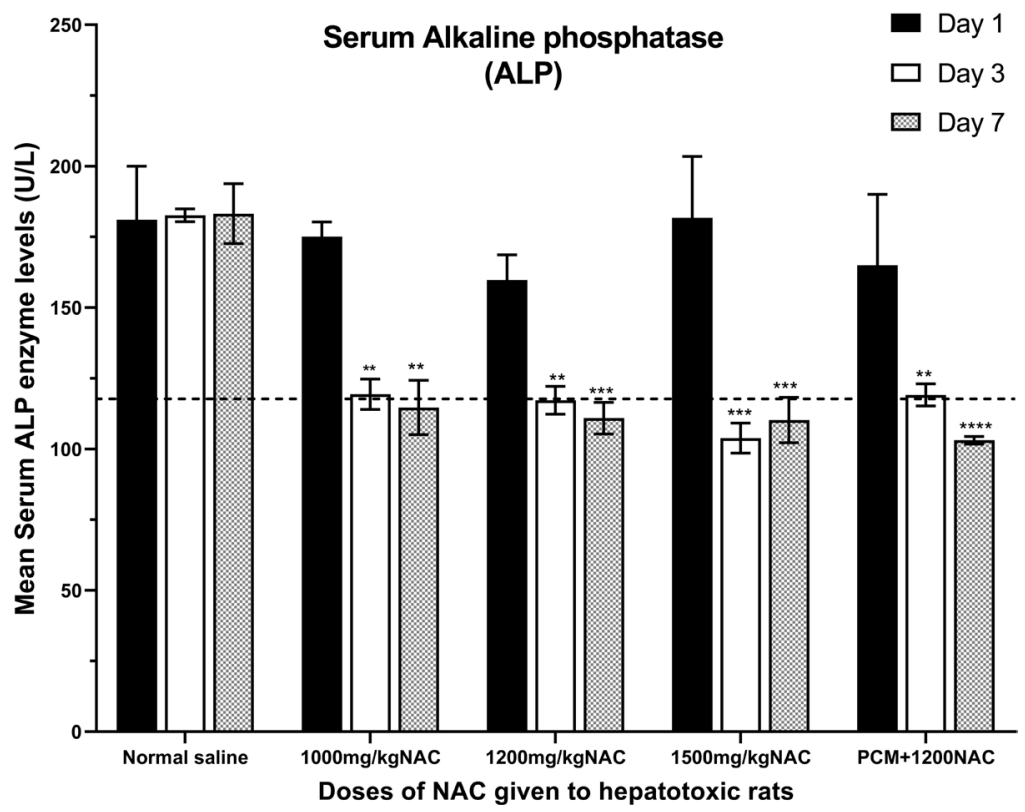

${ }^{*} \mathrm{P}<0.05$ was marked significant. ${ }^{* * *} \mathrm{P}<0.05$ was marked highly significant, NS $=$ Normal saline, $\mathrm{NAC}=\mathrm{N}$-acetyl cysteine, $\mathrm{PCM}=$ Paracetamol; the dotted line indicates normal ALP levels .

Figure 3. Serum ALP levels in hepatotoxic rats treated with different doses of NAC.

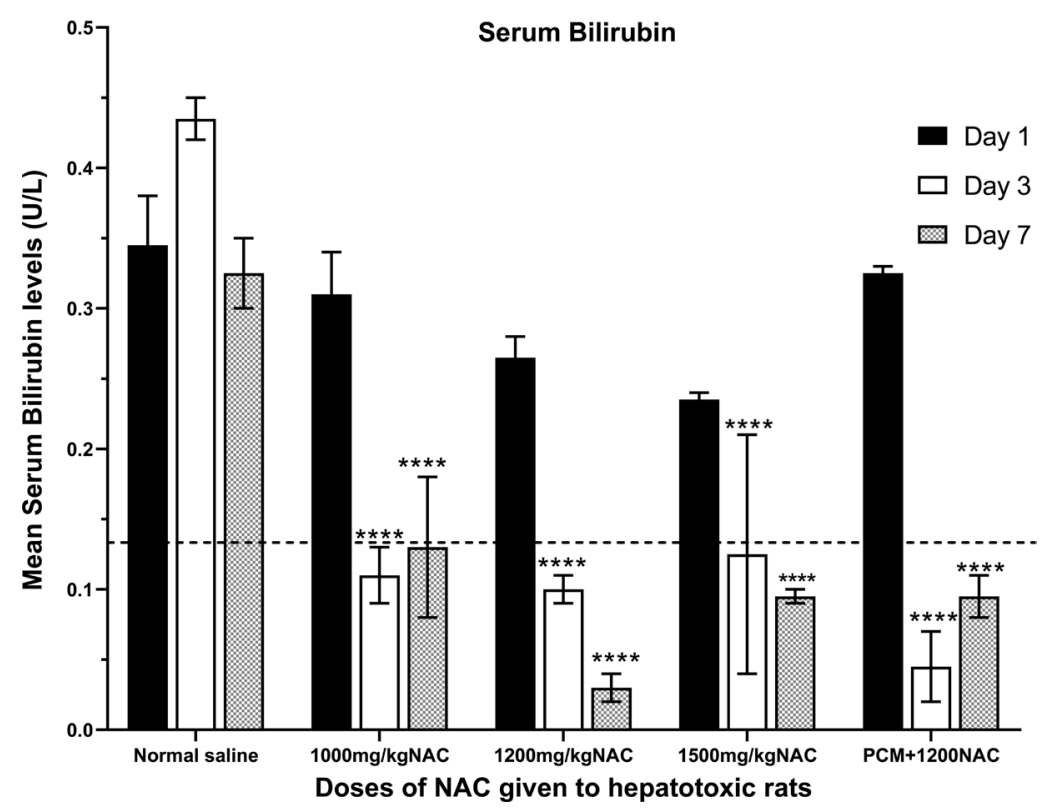

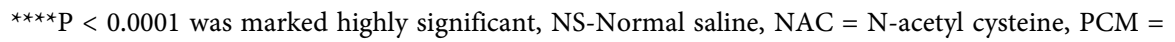
Paracetamol; the dotted line indicates normal bilirubin levels.

Figure 4. Bilirubin levels in hepatotoxic rats treated with different doses of NAC. 
The serum proteins remained in the normal range of $73.30 \pm 1.40$ to $58.40 \pm$ $4.30 \mathrm{~g} / \mathrm{L}$. This means that the liver toxicity developed did not affect the mean total serum proteins.

\section{Histopathology of the liver}

The liver histopathological changes stained with of Hematoxylin and Eosin $(\times 10)$ of all the study animals that received $0.75 \mathrm{mg} / \mathrm{kg}$ paracetamol for 28 days were analyzed. The liver tissue had infiltration of lymphocytes around the portal triad (Figure 5). After treatment with $1200 \mathrm{mg} / \mathrm{kg}$ NAC for 7 days, the liver tissue was normal with no lymphocytes infiltration (Figure 6).

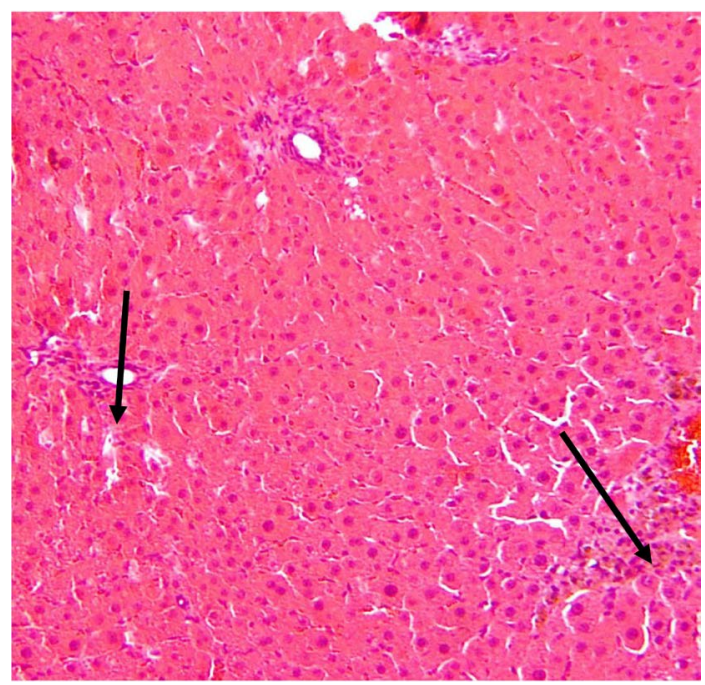

Figure 5. Histopathological appearance of the liver tissue from rats that received a toxic dose of paracetamol: infiltration of lymphocytes around the portal triad $(\times 10)$.

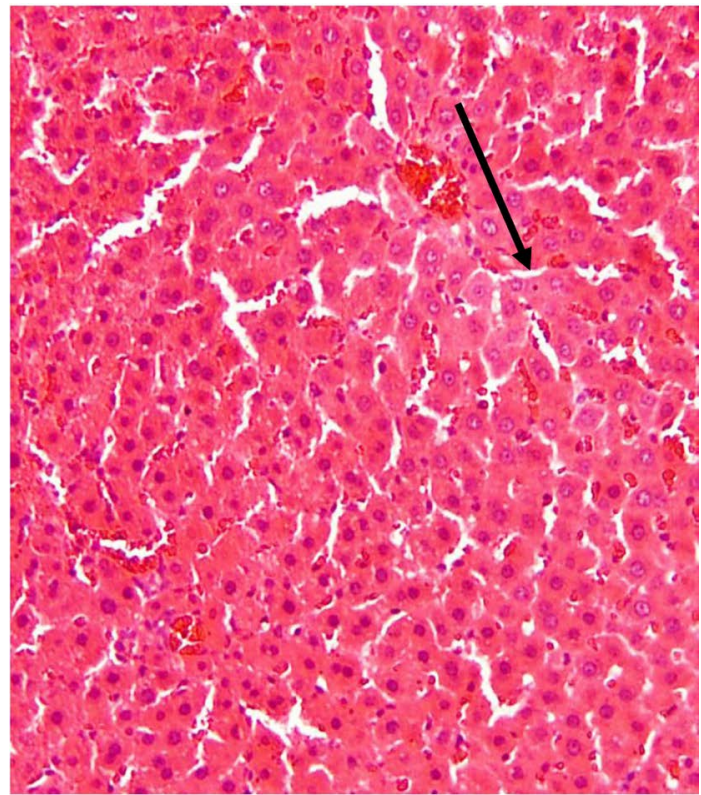

Figure 6. Histopathological appearance of the liver tissue from rats that received a toxic dose of paracetamol and NAC concurrently: normal liver tissue with no lymphocytes infiltration $(\times 10)$. 


\section{Histopathology of the liver}

The liver histopathological changes stained with of Hematoxylin and Eosin (×10) of all the study animals that received $8.05 \mathrm{~g} / \mathrm{kg}$ M. oleifera extract for 28 days were analysed. The liver tissue had infiltration of lymphocytes around the portal triad (Figure 7). After treatment with $1000 \mathrm{mg} / \mathrm{kg}$ NAC for 3 days, the liver tissue had mild infiltration of lymphocytes around the portal triad (Figure 8) and had normal liver tissue with no infiltration of lymphocytes around the portal triad on day 7 (Figure 9).

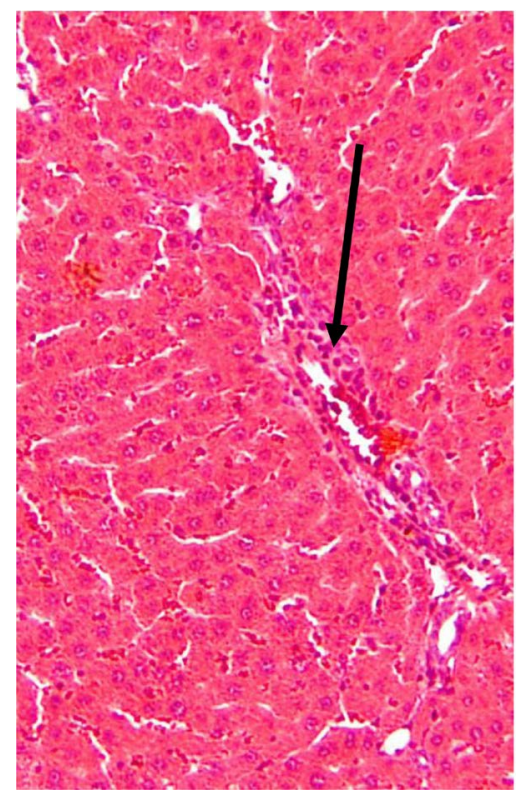

Figure 7. Histopathological appearance of the liver tissue with Moringa toxicity $\mathrm{H} \&$ E- $(\times 10)$. Infiltration of lymphocytes around the portal triad.

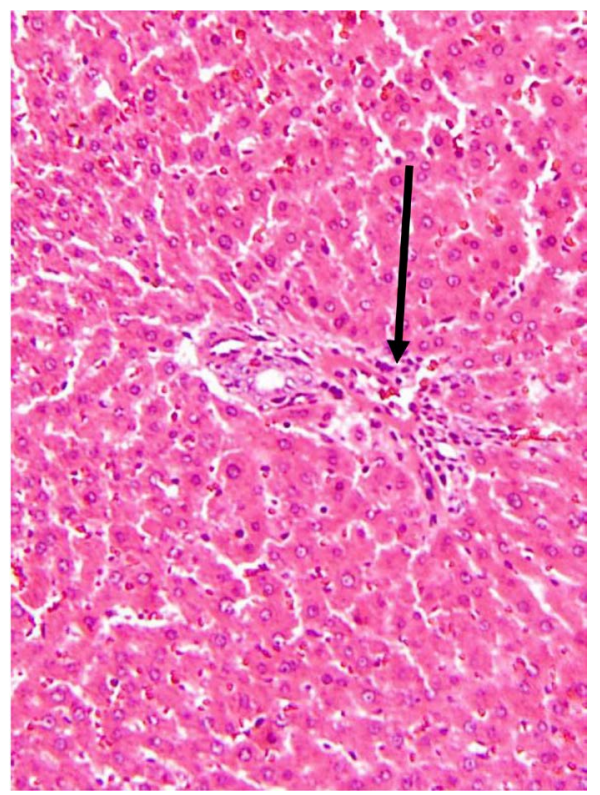

Figure 8. Histopathological appearance of the liver tissue that received $1000 \mathrm{NAC} \mathrm{H} \&$ E- $(\times 10)$. Normal liver tissue with mild infiltration of lymphocytes around the portal triad. 


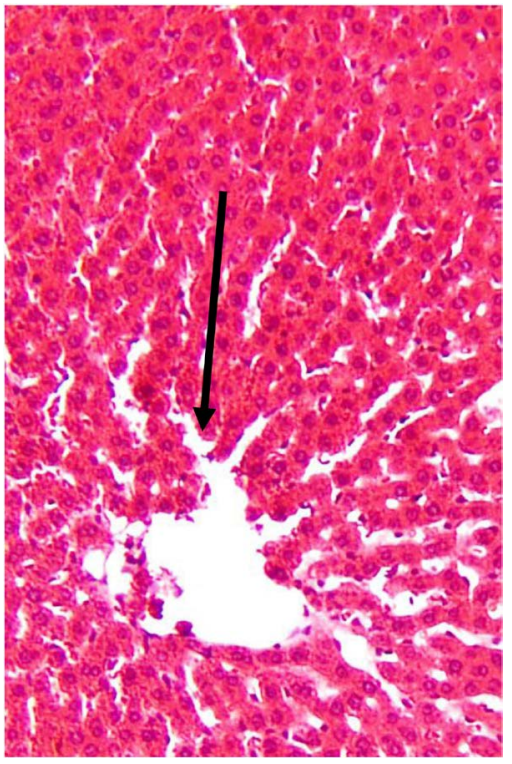

Figure 9. Histopathological appearance of the liver tissue that received $1500 \mathrm{NAC} \mathrm{H} \&$ E- $(\times 10)$. Normal liver tissue with no infiltration of lymphocytes around the portal triad.

\section{Discussion}

The findings from this study demonstrated that NAC has a capability to reverse the sub-cute hepatotoxicity caused by a toxic dose of $M$. oleifera extract in Wistar Albino rats. The mean serum liver enzymes (ALT, AST and ALP) and bilirubin levels in the rats treated with NAC following a $M$. oleifera leaf extract toxic dose, showed a significant $(\mathrm{P}<0.05)$ reduction. The hepatotoxicity that was produced by paracetamol was also reversed. The findings were in agreement with previous studies that focused on the effects of NAC in a variety of biological and pathological processes especially in the management of paracetamol-induced hepatotoxicity [12] [9].

\section{Serum liver enzymes}

There was an elevation in liver enzymes (ALT, AST and ALP) in rats given a toxic dose $8.05 \mathrm{mg} / \mathrm{kg}$ of $M$. oleifera leaf extract for 28 days. These results were in agreement with several researchers who have reported perturbations in the activities of ALT, AST, and ALP in liver during $M$. oleifera leaf aqueous extractinduced hepatotoxicity [13] [14]. The liver is the most vulnerable organ in the body to toxic substances and chemicals and therefore it was affected by toxic levels of $M$. oleifera leaves aqueous extract with specific elevated transaminase enzymes; Alanine transaminase (ALT), Aspartate transaminase (AST) and Alkaline phosphatase (ALP) [14] [15] [16]. The elevated liver enzymes indicate inflammation or damage to cells in the liver. Inflamed or injured liver cells, leak higher amounts of chemicals, including enzymes such as ALP, AST and ALP, into the bloodstream, resulting into their elevated levels [17].

$\mathrm{N}$-acetyl cysteine may have reversed oxidative stress that was caused by $M$. oleifera leaf extract, through increased glutathione synthesis, thus providing more substrate for the detoxification [18]. NAC may also have reduced the liver dam- 
age by its ability to promote cell survival through activating extracellular signal-regulated kinase pathway plus directly modifying the activity of several proteins [11].

A rise in alkaline phosphatase indicates damage to the liver cells including the biliary system. Therefore, the increase in serum alkaline phosphate may be considered as a sensitive indicator of cholestasis which is also supported by significant increase in total bilirubin in rats that received $M$. oleifera aqueous leaf extract [14]. The reduction noted in ALP levels was because of antioxidant properties of NAC.

\section{Serum total protein changes}

Liver synthesizes plasma protein including albumin, globulin and fibrinogen. As there were no significant changes in total protein levels in control groups and treatment groups, the synthetic function of the liver was preserved.

\section{Histopathological liver changes}

Paracetamol induced-hepatotoxicity histopathological features show infiltration of lymphocytes around the portal triad (Figure 5). On treatment with NAC for 7 days, the normal liver tissue was observed (Figure 6). This indicated reversal of the paracetamol induced hepatotoxicity by NAC. In relation to the rats that received $M$. oleifera aqueous extract for 28 days, the liver tissue features of infiltration shown by of the lymphocytes around the portal triad, confirmed hepatotoxicity in the same way as what happened in the rats that received paracetamol (Figure 7). This confirms that half LD50 of $M$. oleifera aqueous extract given orally to rats for 28 days causes hepatotoxicity as was reported by other researchers [7]. The group that received $1500 \mathrm{mg} / \mathrm{Kg}$ of NAC for 3 days had normal liver tissue with mild infiltration of lymphocytes around the portal triad (Figure 8) and had normal liver tissue with no infiltration of lymphocytes around the portal triad (Figure 9). Xenobiotics and intermediates may have disturbed the redox balance and provoked excessive production of ROS in the hepatocytes, which oxidized lipids, proteins, DNA, and other macromolecules causing disruption of cell processes, thus injuring hepatocytes [18].

Due to the fact that $M$. oleifera leaves are taken by humans and animals due to its nutrition and medicinal values without standardization, there is a great chance of taking in toxic doses of the plant leaves. This study suggests an antidote for $M$. oleifera leaves over dose.

\section{Conclusion}

NAC reverses $M$. oleifera leaves aqueous extract-induced sub-acute hepatotoxicity in Wistar Albino rats.

\section{Acknowledgements}

This work was financially supported by the Directorate of Research and Graduate Training, CARNEGIE NERLP PROGRAMME, Makerere University as part of Post Doctoral training. 


\section{Conflicts of Interest}

The authors declare no conflicts of interest regarding the publication of this paper.

\section{References}

[1] Sharief, D. (2014) Effect of Moringa oleifera against Stannous Chloride Toxicity in Rats Rattus norvegicus. International Journal of Pharmaceutical \& Biological Archive, 4, 771-774.

[2] Verma, S. and Singh, S. (2008) Current and Future Status of Herbal Medicines. Veterinary World, 1, 347-350. https://doi.org/10.5455/vetworld.2008.347-350

[3] Mbikay, M. (2012) Therapeutic Potential of Moringa oleifera Leaves in Chronic Hyperglycemia and Dyslipidemia: A Review. Frontiers in Pharmacology, 3, 24. https://doi.org/10.3389/fphar.2012.00024

[4] Kasolo, J.N., Bimenya, G.S., Ojok, L., Ochieng, J. and Ogwal-Okeng, J.W. (2010) Phytochemicals and Uses of Moringa oleifera Leaves in Ugandan Rural Communities. Journal of Medicinal Plants Research, 4, 753-757.

[5] Konmy, B.B., Olounladé, P.A., Azando, E.B.V. and Hounzangbe-Adote, S.E.G. (2016) A Review on Phytochemistry and Pharmacology of Moringa oleifera Leaves (Moringaceae). Journal of Pharmacognosy and Phytochemistry, 5, 325.

[6] Kasolo, J.N., Bimenya, G.S., Okwi, A.L., Othieno, E.M. and Ogwal-Okeng, J.W. (2012) Acute Toxicity Evaluation of Moringa oleifera Leaves Extracts of Ethanol and Water in Mice. The African Journal of Animals \& Biomedical Sciences, 7, 40-44.

[7] Kasolo, J.N., Bimenya, G.S., Ojok, L. and Ogwal-Okeng, J.W. (2012) Sub-Acute Toxicity Evaluation of Moringa oleifera Leaves Aqueous and Ethanol Extracts in Swiss Albino Rats. International Journal of Medicinal Plant Research, 1, 75-81.

[8] Atkuri, K.R., Mantovani, J.J., Herzenberg, L.A. and Herzenberg, L.A. (2007) N-Acetylcysteine a Safe Antidote for Cysteine/Glutathione Deficiency. Current Opinion in Pharmacology, 7, 355-359. https://doi.org/10.1016/j.coph.2007.04.005

[9] Zafarullah, M., Li, W., Sylvester, J. and Ahmad, M. (2003) Molecular Mechanisms of N-Acetylcysteine Actions. Cellular and Molecular Life Sciences CMLS, 60, 6-20. https://doi.org/10.1007/s000180300001

[10] Gordon, K. (2001) The OECD Guidelines and Other Corporate Responsibility Instruments.

[11] Harborne, J. (1984) Methods of Plant Analysis. In: Phytochemical Methods, Springer, Berlin, 1-36. https://doi.org/10.1007/978-94-009-5570-7

[12] Arfsten, D.P., Johnson, E.W., Thitoff, A.R., Jung, A.E., Wilfong, E.R., Lohrke, S.M., Bobb, A.J., et al. (2004) Impact of 30-Day Oral Dosing with N-acetyl-L-cysteine on Sprague-Dawley Rat Physiology. International Journal of Toxicology, 23, 239-247. https://doi.org/10.1080/10915810490502041

[13] Adedapo, A., Mogbojuri, O. and Emikpe, B. (2009) Safety Evaluations of the Aqueous Extract of the Leaves of Moringa oleifera in Rats. Journal of Medicinal Plants Research, 3, 586-591.

[14] Ekam, V. and Ebong, P. (2007) Serum Protein and Enzyme Levels in Rats Following Administration of Antioxidant Vitamins during Caffeinated and Non-Caffeinated Paracetamol Induced Hepatotoxicity. Nigerian Journal of Physiological Sciences, 22, 65-68. https://doi.org/10.4314/njps.v22i1-2.54894

[15] Olayemi, A.T., Olanrewaju, M.J. and Oloruntoba, A.C. (2016) Toxicological Evalua- 
tion of Moringa oleifera Lam Seeds and Leaves in Wistar Rats. Pharmacognosy Communications, 6, 100-111. https://doi.org/10.5530/pc.2016.2.8

[16] Fakurazi, S., Sharifudin, S.A. and Arulselvan, P. (2012) Moringa oleifera Hydroethanolic Extracts Effectively Alleviate Acetaminophen-Induced Hepatotoxicity in Experimental Rats through Their Antioxidant Nature. Molecules, 17, 8334-8350. https://doi.org/10.3390/molecules17078334

[17] Lauterburg, B.H., Corcoran, G.B. and Mitchell, J.R. (1983) Mechanism of Action of $\mathrm{N}$-acetylcysteine in the Protection against the Hepatotoxicity of Acetaminophen in Rats in Vivo. The Journal of Clinical Investigation, 71, 980-991. https://doi.org/10.1172/JCI110853

[18] Han, D., Shinohara, M., Ybanez, M.D., Saberi, B. and Kaplowitz, N. (2010) Signal Transduction Pathways Involved in Drug-Induced Liver Injury. In: Adverse Drug Reactions, Springer, Berlin, 267-310. https://doi.org/10.1007/978-3-642-00663-0_10 